\title{
Geological Feasibility of Underground Oil Storage in Jintan Salt Mine of China
}

\author{
Xilin Shi, ${ }^{1}$ Wei Liu, ${ }^{2}$ Jie Chen, ${ }^{1,2}$ Chunhe Yang, ${ }^{1}$ Yinping Li, ${ }^{1}$ Hongling Ma, \\ Huihua Peng, ${ }^{2}$ Tongtao Wang, ${ }^{1}$ and Xuqiang $\mathrm{Ma}^{3}$ \\ ${ }^{1}$ State Key Laboratory of Geomechanics and Geotechnical Engineering, Institute of Rock and Soil Mechanics, \\ Chinese Academy of Sciences, Wuhan 430071, China \\ ${ }^{2}$ State Key Laboratory of Coal Mine Disaster Dynamics and Control, Chongqing University, Chongqing 400044, China \\ ${ }^{3}$ Jintan Salt Mine, China Salt Jintan Co., Ltd., Jintan 213200, China
}

Correspondence should be addressed to Wei Liu; guarenliuwei@126.com and Jie Chen; jiechen023@cqu.edu.cn

Received 23 February 2017; Accepted 17 May 2017; Published 14 June 2017

Academic Editor: Andres Sotelo

Copyright (C) 2017 Xilin Shi et al. This is an open access article distributed under the Creative Commons Attribution License, which permits unrestricted use, distribution, and reproduction in any medium, provided the original work is properly cited.

\begin{abstract}
A number of large underground oil storage spaces will be constructed in deep salt mines in China in the coming years. According to the general geological survey, the first salt cavern oil storage base of China is planned to be built in Jintan salt mine. In this research, the geological feasibility of the salt mine for oil storage is identified in detail as follows. (1) The characteristics of regional structure, strata sediment, and impermeable layer distribution of Jintan salt mine were evaluated and analyzed. (2) The tightness of cap rock was evaluated in reviews of macroscopic geology and microscopic measuring. (3) According to the geological characteristics of Jintan salt mine, the specific targeted formation for building underground oil storage was chosen, and the sealing of nonsalt interlayers was evaluated. (4) Based on the sonar measuring results of the salt caverns, the characteristics of solution mining salt caverns were analyzed. In addition, the preferred way of underground oil storage construction was determined. (5) Finally, the results of closed well observation in solution mining salt caverns were assessed. The research results indicated that Jintan salt mine has the basic geological conditions for building large-scale underground oil storage.
\end{abstract}

\section{Introduction}

Strategic petroleum reserve (SPR) is a significant part of China's energy structure, and perfecting China's strategic oil reserve is also a necessary part of the 13th five-year plan for energy of China. In 2015, China's dependence on imported oil increased to a record $63.7 \%$ [1], so it is urgent to construct more oil reserve. China's strategic petroleum reserve has been planned to complete from 2003 to 2020, which is divided into three periods. Until 2020, oil reserve base construction will be completed, and then China's petroleum reserve capacity will increase to about $85 \times 10^{9}$ t, equivalent to 90 days' oil net imports. Currently, the second phase of China's strategic petroleum reserve has been accomplished; however, most of reserve bases are located at offshore cities on the ground. Taking oil safety and regional economy harmonious development into account, the government has to switch reserve base from the offshore cities to inland, as well as from the construction of surface tanks to underground storage facilities.

Rock salt has been recognized as having low permeability [2], low porosity [3], high ductility $[4,5]$, and water-soluble mining [6]. For these characteristics, rock salt is widely considered as the ideal host rock for hydrocarbon energy (gas or oil) storage [7-9]. Usually, salt cavern oil storage group is constructed in deep salt mine, hundred meters to thousand meters in depth, by water-solution mining method (see Figure 1). Salt cavern oil storage group is composed of many salt caverns, and the storage capacity of individual cavern is more than $20 \times 10^{4} \mathrm{~m}^{3}$. As a result, the total oil storable volume is up to millions or even tens of million cube meters. Nowadays, many countries have carried out largescale oil reserves in underground salt caverns. For instance, in Germany, $42 \%$ of crude oil is stored in salt caverns. In the USA, the strategic oil reserves are mostly located in 


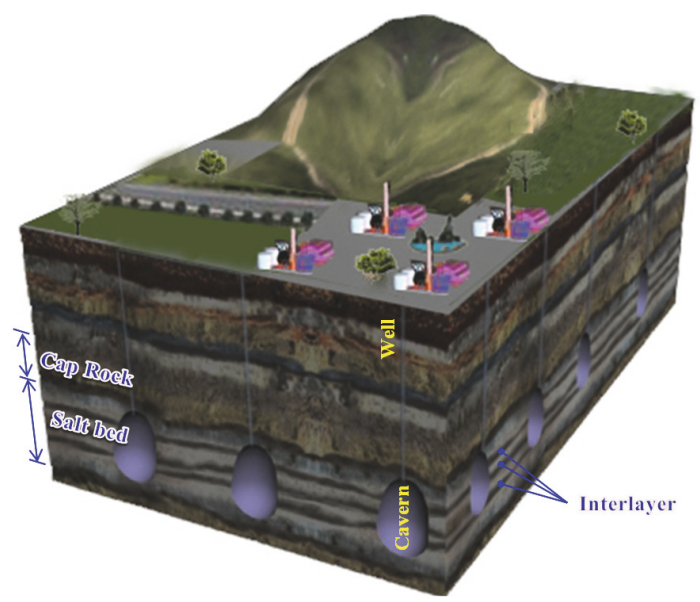

FIGURE 1: Illustration of salt cavern oil storages in a bedded salt formation.

underground salt caverns. In addition, the construction cost on the ground is about $\$ 15 \sim 18$ per barrel, while it is more than $\$ 30$ per barrel in the digging rock cave. However, the construction cost is low, $\$ 1.5$ per barrel, in underground salt caverns that are located in the Gulf of Mexico, USA. Therefore, the outstanding advantages of underground salt cavern oil storage include large storage capacity, high security, and remarkable economic benefits.

In China, the formation conditions of many salt mines with wide range distribution are good enough to construct salt caverns [10]. The salt formations in China are mainly thin, bedded, and highly heterogeneous [11]. The geological tectonics, corrosion [12,13], rock mechanics [14-17] and creep damage characteristics [18-20], gas storage tightness [21, 22], and risk assessment [23, 24] are thoroughly investigated. After more than ten years' research and practice, China has begun to carry out the demonstration or construction of salt cavern oil storage in central and eastern regions.

Owing to the outstanding advantages of salt cavern oil storage and abundant salt resources, China has made a preliminary plan of the third phase of the national petroleum reserve, which is going to be built in deep salt mine. In consideration of the distribution of Chinese salt mine [10], the construction of salt cavern oil storage can be considered in the economic developed districts of Middle East, such as Jintan salt mine, which is most likely to become the China's first salt cavern oil storage. In this manuscript, the geological feasibility of underground oil storage in Jintan salt mine had been analyzed from the Jintan geological data and related rock parameters including the geological characters, tightness of cap rock, tightness of targeted strata, and sealing of existing salt caverns (Figure 2), from which we could judge whether Jintan salt mine strata was suitable for large-scale oil storage.

\section{Geological Evaluation of Jintan Salt Mine}

2.1. Regional Structure Characteristics. Figure 3 shows the tectonic map of Jintan salt mine which is a typical lacustrine fault cut halite subsag controlled by boundary faults and belongs to a lacustrine deposition. According to the characteristics of the base ups and downs and sedimentation development, as well as the spatial distribution law, the salt mine sag has one apophasis and two subsags along northeast. Thus it can be seen that the geological structure of the salt mine is simple and clear, which is advantageous to the tightness of underground oil storage group.

As shown in Figure 3, there are four big faults, fault $\mathrm{Fx}$, fault $\mathrm{Fz}$, fault $\mathrm{Fb}$, and fault $\mathrm{Fg}$, and three small faults derived from fault $\mathrm{Fz}$ around the salt mine. Fortunately, there is no big fault found in the principal area of the salt mine. Importantly, the four big faults around the salt basin are all normal faults, which have been in inactive state since the Cenozoic. And the fault planes have also been in the state of sealing and tightness; the longitudinal direction of fault does not cut the salt rock. What is more, both sides of the faults are rock salt and mudstone with excellent plasticity and compact structure, resulting in remarkable sealing capacity. Therefore, a certain safe distance can ensure the security of oil caverns as long as the four big faults, Fx, Fz, Fb, and Fg, are avoided around the salt basin.

As shown in Figure 3, the area, thickness, and sedimentary center thickness of saliferous strata are $60.5 \mathrm{~km}^{2}, 67.85 \sim$ $230.95 \mathrm{~m}$, and $200 \mathrm{~m}$, respectively, and the distribution of salt layers is relatively stable in plane and vertical direction in Jintan mining area. Besides, the distribution of salt layers is gentle and generally tilts towards the northwest with low dip angle $\left(<10^{\circ}\right)$. Such a small dip angle is beneficial to the shape control of oil storage during the salt cavern leaching process. It is suitable for the construction of underground oil storage by water leaching method.

2.2. Regional Earthquake Characteristics. According to the historical seismic data of Jintan salt mine and its adjacent area [25], there were a total of 26 earthquakes, which were greater than level 3, since $\mathrm{AD} 320$. The maximum earthquake intensity was 6 , and the common intensity was 3 5. However, only 7 quakes happened in Jintan area with the maximum magnitude of 3.5. According to the seismic ground motion parameter zonation map of China [26], the seismic peak ground acceleration and the characteristic period of the seismic response spectrum in engineering area are $0.05 \mathrm{~g}$ and $0.40 \mathrm{~s}$, respectively. According to the seismic history of Jintan region, the seismic precautionary intensity of this region is VI. Therefore, there is little influence on the regional stability of Jintan area due to tectonic activities. In the engineering construction, the designed requirement for seismic resistance of VII can sufficiently guarantee the safety of oil storage against earthquake.

2.3. Strata Sediment Characteristics. Based on the investigations of the existing geological exploration data of Jintan salt mine, we chose the typical exploration Well M1\# (the location was marked in Figure 3) as the specific research object. As shown in Figure 3, Well M1\# is located near the center of salt mine deposition, which has very good representativeness of the salt mine.

The Paleogene stratum is covered by Quaternary in the Cenozoic of Jintan basin, which is revealed by drilling data 


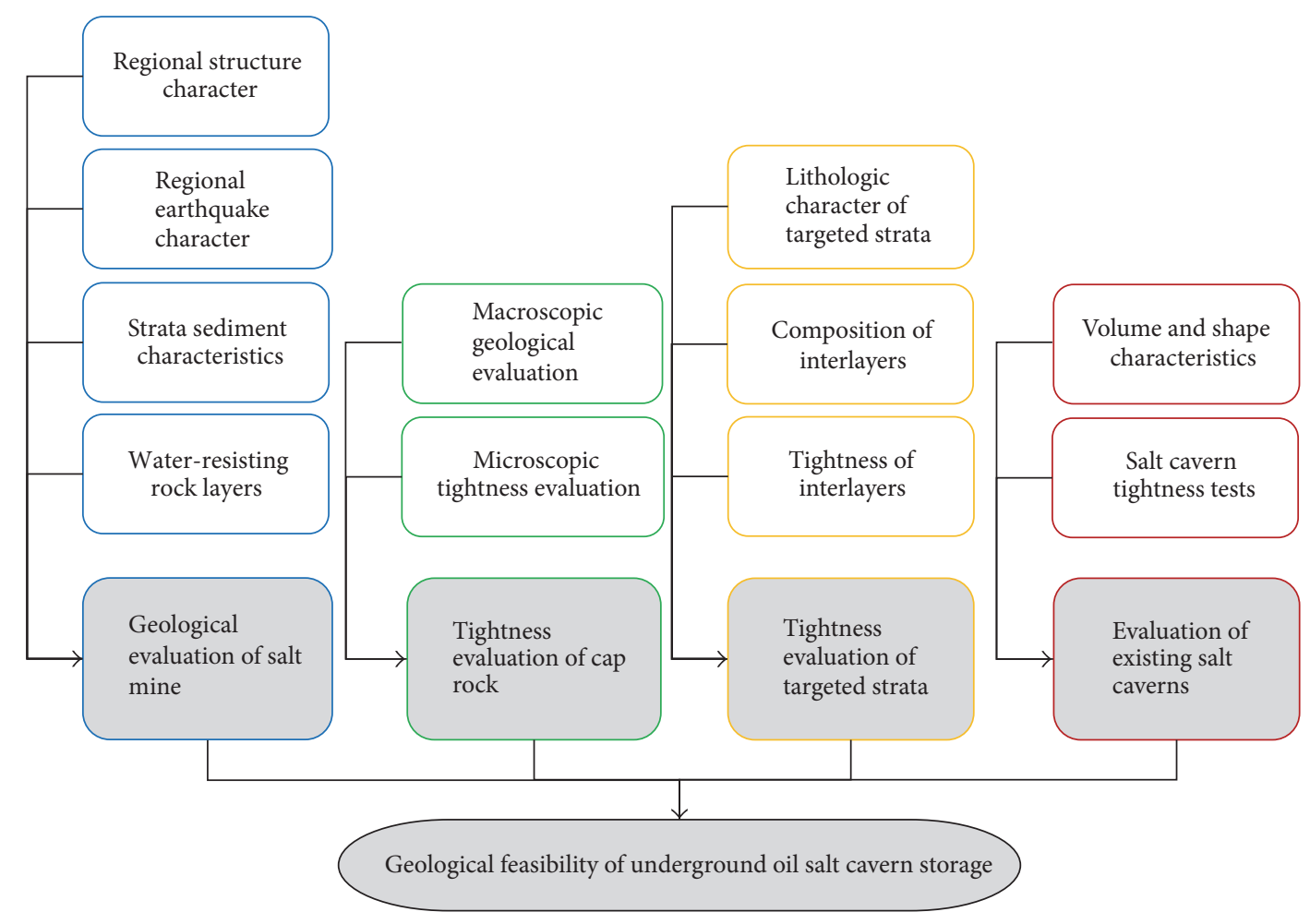

FIGURE 2: Evaluation system of geological feasibility on underground oil storage.

inside the basin. Besides, the Tertiary is absent in this area, whereas the Quaternary loosely covers the entire area. Table 1 shows the strata information of Jintan salt mine, according to the comprehensive salt mine strata histogram [10] and exploration well data [27]. As shown in Table 1, the Paleogene is composed of Funing, Dainan, and Sanduo group from bottom to top. The saliferous strata distribute in the upper part of the Funing group, that is, the 4 th part $\left(\mathrm{Ef}^{4}\right)$, which was deposited in shallow lake under the condition of static and dynamic water exchange environment in early sedimentary period. The profile structure of $\mathrm{Ef}^{4}$ is relatively simple. The bottom of $\mathrm{Ef}^{4}$ is mainly gypsum-containing glauberite mudstone; the top of $\mathrm{Ef}^{4}$ is mainly glauberite mudstone and mudstone. Comparatively, halite is included in the middle of $\mathrm{Ef}^{4}$. The thickness of halite layer with $80 \%$ salt content is high enough to ensure the efficiency of shape in the construction of oil storage. In addition, the moderate depth of $\mathrm{Ef}^{4}$ is $809.38 \sim 1045.57 \mathrm{~m}$, which is also very suitable for the security and stable operation of underground oil storage.

2.4. Water-Resisting Rock Layers. Owing to the good watersoluble property of salt rock, salt formation which is not connected with the underground water system is a necessary condition for contribution of oil storage.

According to the hydrogeological characteristics of Jintan salt mine, there are effective water-resisting layers with considerable thickness along the longitudinal direction and above and below the salt layer, which are mainly reflected in the following three aspects:

(1) Basalt in the 1st part of Sanduo group: a wide distribution area, accumulated thickness of $50 \sim 120 \mathrm{~m}$, stable thickness of $50 \mathrm{~m}$ in the center of basin, poor fracture, and good waterproof property

(2) The 2nd part of Sanduo group and Dainan group: located between basalt and the top of salt layers, containing mudstone, gray mudstone, and sandy mudstone, total thickness of $500 \mathrm{~m}$, poor fracture, and argillaceous, calcareous, and nitrate-filled fracture

(3) The bottom of salt layer: dense-hard mudstone, silty mudstone, poor fracture, total thickness of about $100 \mathrm{~m}$ only below the salt layer in the 4 th part of Funing group, and mudstone in the 3rd part of Funing group

From the above, it can be seen that the hydrogeological conditions of Jintan salt mine are so simple that they would not have bad influence on the salt layers of oil storage.

\section{Tightness Evaluation of Cap Rock}

In salt cavern oil storage, the crude oil may leak through the salt roof, the steel casings, or the cemented annulus. In geological aspects, the tightness of the cap rock is the basis to ensure the security of oil storage. The factors that influence 
TABLE 1: Stratum information of Jintan salt mine.

\begin{tabular}{|c|c|c|c|c|c|c|}
\hline \multirow[b]{2}{*}{ System } & \multicolumn{2}{|c|}{ Stratum } & \multirow[b]{2}{*}{ Symbol } & \multicolumn{2}{|c|}{ M1 } & \multirow[b]{2}{*}{ Lithotype } \\
\hline & Group & Part & & $\begin{array}{l}\text { Depth } \\
(\mathrm{m})\end{array}$ & $\begin{array}{l}\text { Apparent thickness } \\
(\mathrm{m})\end{array}$ & \\
\hline Quaternary & Dongtai & - & Qd & 17.0 & 17.0 & Sandy clay, mudstone, glutenite \\
\hline \multirow{7}{*}{ Paleogene } & \multirow{2}{*}{ Sanduo } & 2nd & $\mathrm{Es}^{2}$ & 371.5 & 354.5 & $\begin{array}{l}\text { Top: conglomeratic sandstone, brown } \\
\text { silty mudstone } \\
\text { Middle: powder sandstone, silty } \\
\text { sandstone, mudstone } \\
\text { Bottom: mudstone, sandy mudstone }\end{array}$ \\
\hline & & 1st & $\mathrm{Es}^{1}$ & 566.5 & 195.0 & $\begin{array}{l}\text { Top: basalt, metamorphic silty tuff } \\
\text { Middle: gray silty mudstone } \\
\text { Bottom: mudstone, gray mudstone }\end{array}$ \\
\hline & \multirow[b]{2}{*}{ Dainan } & 2nd & $\mathrm{Ed}^{2}$ & 757.0 & 190.5 & $\begin{array}{l}\text { Silty powder sandstone, mudstone, } \\
\text { conglomeratic mudstone }\end{array}$ \\
\hline & & 1st & $\mathrm{Ed}^{1}$ & 832.5 & 75.5 & $\begin{array}{l}\text { Gray mudstone, sandy mudstone, } \\
\text { mudstone, dolomitic mudstone }\end{array}$ \\
\hline & \multirow{3}{*}{ Funing } & \multirow{3}{*}{4 th } & \multirow{3}{*}{$\mathrm{Ef}^{4}$} & 860.0 & 27.5 & $\begin{array}{l}\text { Top: gypsum mudstone, dolomitic } \\
\text { mudstone, mudstone }\end{array}$ \\
\hline & & & & 1055.0 & 195.0 & $\begin{array}{l}\text { Middle: argillaceous rock salt, nitrate salt } \\
\text { rock, thenardite salt rock, nitrate } \\
\text { mudstone, salt mudstone, mudstone }\end{array}$ \\
\hline & & & & 1110.0 & 55.0 & Bottom: mudstone \\
\hline
\end{tabular}

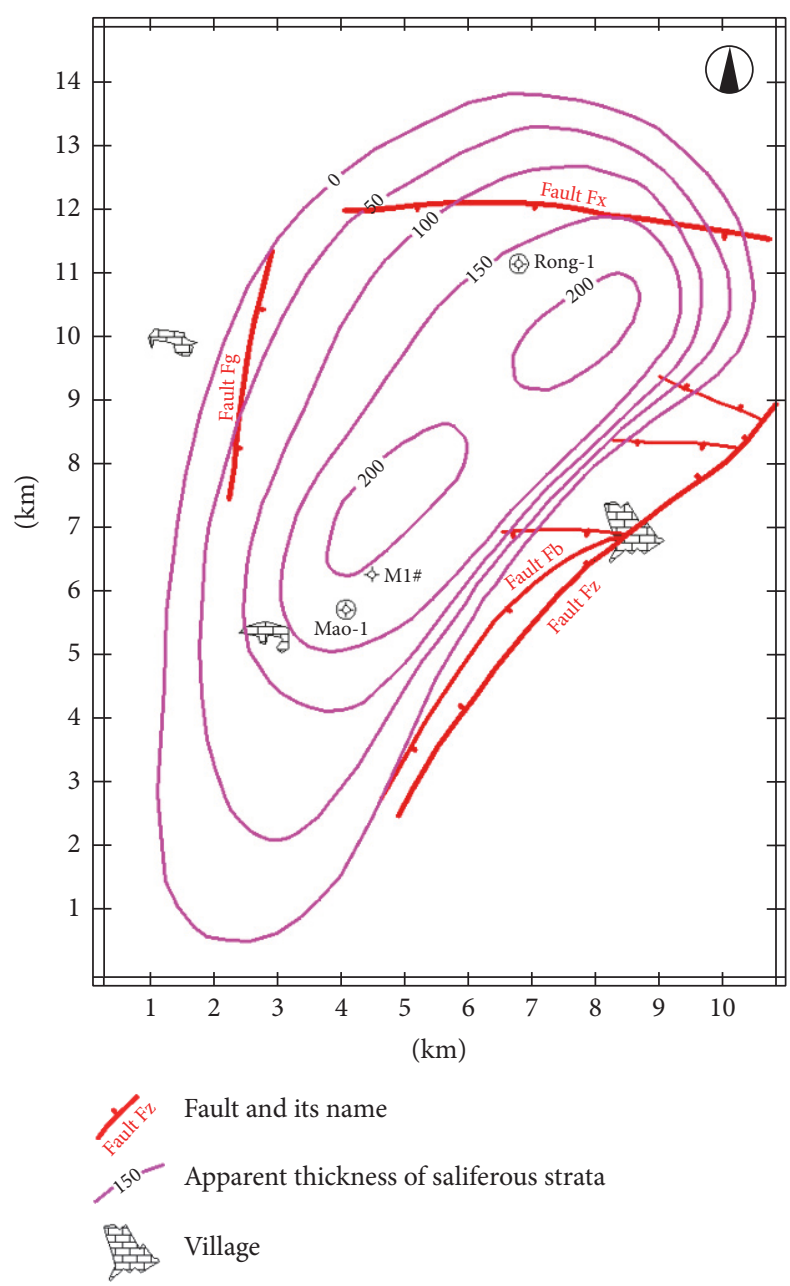

FIGURE 3: Tectonic map and thickness of saliferous strata of Jintan salt mine. the tightness of cap rock include the fault, homogeneity, and gas permeability of the cap rock.

\subsection{Macroscopic Geological Evaluation}

3.1.1. Macroscopic Sealing Characteristic of Direct Cap Rock. The direct cap rock of the salt-bearing is located in $\mathrm{Ed}^{1}$ and the top of $\mathrm{Ef}^{4}$, with the depth and thickness being $800 \sim 1140 \mathrm{~m}$ and $96 \sim 150 \mathrm{~m}$, respectively. From bottom to top, the direct cap rock consists of glauberite-containing mudstone, cloud gray mudstone, gypsum mudstone, glauberitecontaining cloud mudstone, cloud mudstone, and ash black mudstone, which are all tight geomaterials with good sealing capacity. In addition, the distribution of the direct cap rock in the whole salt mine is stable and continuous, with a mean thickness over $120 \mathrm{~m}$ overlying the whole salt-bearing. Therefore, the direct cap rock is able to be the first effective barrier to prevent leakage of crude oil to the above strata.

3.1.2. Macroscopic Sealing Characteristic of Indirect Cap Rock. The indirect cap rock is the strata overlying the direct cap rock, acting as the second barrier of the underground oil storages. The indirect cap rock of Jintan salt mine consists of thick mudstone stratum located between the top of direct cap rock and the bottom of Dainan group. From the thickness distribution map (Figure 3), the maximum thickness is located in the north, whereas the thinnest is located in the southern edge of the tectonic uplift area. Despite that, the minimum thickness of indirect cap rock is up to $340 \mathrm{~m}$, indicating that the whole indirect cap rock is thick enough, which is also beneficial to the tightness. Hence, these strata behave as the second effective barrier to prevent leakage of crude oil to the land surface. 
TABLE 2: The permeability and breakthrough pressure of Well M1\#.

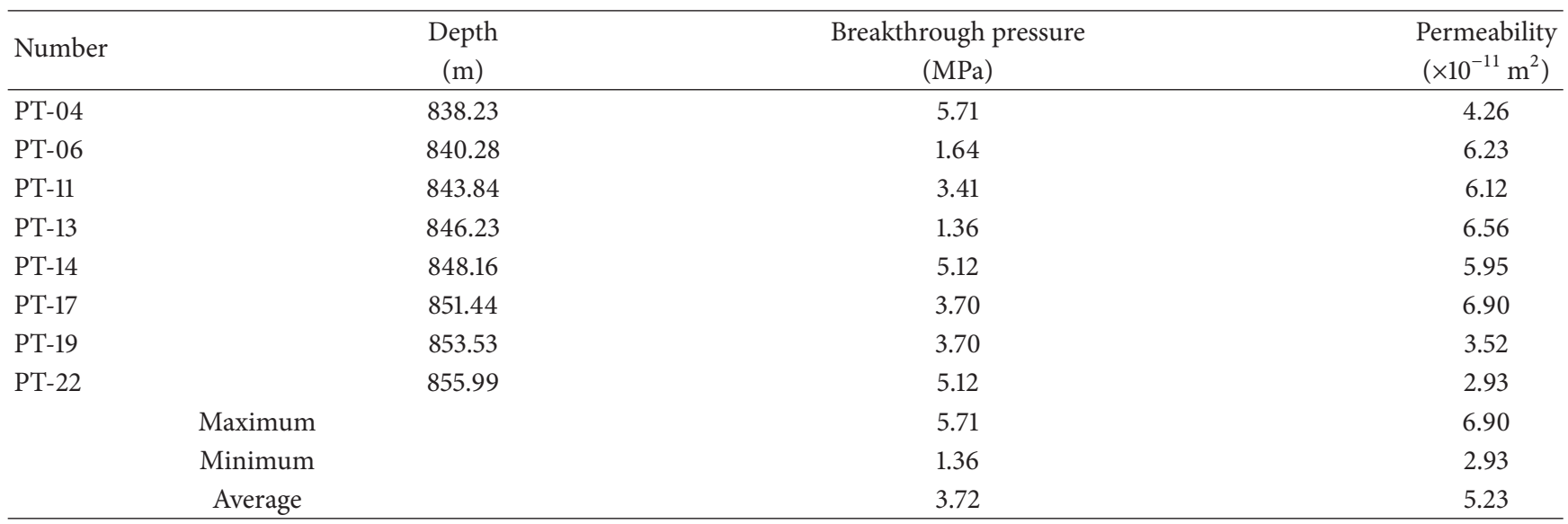

3.1.3. Sealing Characteristic Revealed by Drilling Data. According to the drilling data of Well M1\# [28], there was no drilling mud leakage during the whole drilling process, illustrating that there are no big cracks in the entire drilled strata. Also, the bore diameter was not enlarged evidenced by logging, showing that the closure of filled seam was good under these geological conditions.

Based on above analysis, the direct and indirect cap rocks of Jintan salt mine can act as effective overlying barriers to prevent the underground oil storage from groundwater erosion.

3.2. Microscopic Tightness Evaluation. The microscopic sealing capacity of cap rock mainly depends on the permeability of rock, that is, permeability and breakthrough pressure. Table 2 shows the test results of permeability and breakthrough pressure of Well M1\# carried out by the authors and our cooperators [27]. Considering the seepage direction of crude oil, the results show the sealing capacity of the cap rock in the vertical direction. For the cap rock cores with length of about $50 \mathrm{~mm}$, it is found that the breakthrough pressure $(1.36 \sim 5.71 \mathrm{MPa}$; mean value: $3.72 \mathrm{MPa})$ is high and the permeability $\left(2.93 \sim 6.90 \times 10^{-11} \mathrm{~m}^{2}\right.$; average is $5.23 \times$ $10^{-11} \mathrm{~m}^{2}$ ) is low. The data indicates that the cap rock can be used as effective overlying strata of oil storage.

\section{Tightness Evaluation of Targeted Strata for Oil Storage}

According to the analysis of strata information (Table 1), the saliferous strata are located in $\mathrm{Ef}^{4}$. The targeted strata for oil storage constructed by solution mining method can be selected in the middle of $\mathrm{Ef}^{4}$.

To further investigate the characteristics of rock cores in $\mathrm{Ef}^{4}$, the rock cores of well M1\# were investigated, which were drilled from 834.86 to $1065.66 \mathrm{~m}$ (covering the entire $\mathrm{Ef}^{4}$ ), and the core recovery rate was $97.5 \%$, suggesting that the targeted strata were fairly complete. Combining the drilling information of Well M1\# with analytical tests of cores $[27,28]$, the tightness evaluation of targeted strata for oil storage will be evaluated below.

4.1. Lithologic Characteristics of Targeted Strata. According to the profile characteristics of salt layer revealed by Well $\mathrm{M} 1 \#, \mathrm{Ef}^{4}$ was divided into three sections from top to bottom, namely, top of salt bed, salt bed, and bottom of salt bed, as follows.

4.1.1. Top of Salt Bed (Immediate Roof of Oil Storage). In this section, the depth is $832.5 \sim 860.0 \mathrm{~m}$ and the apparent thickness is $27.5 \mathrm{~m}$. The lithology is mainly gray gypsum mudstone, grey dolomitic mudstone, grey mudstone, and dark brown mudstone, which are all dense and hard and can be used as the ideal roof of salt cavern oil storage.

4.1.2. Salt Bed (Targeted Strata of Oil Storage). In this section, the depth is $860.0 \sim 1055.0 \mathrm{~m}$ and the apparent thickness is $195.0 \mathrm{~m}$. The lithology is mainly grey argillaceous salt rock, nitrate salt rock, nitrate argillaceous salt rock, thenardite salt rock with celadon mudstone, nitrate mudstone, gray salt mudstone, mudstone, and dark brown mudstone, as shown in Table 3. The thickness of single salt layer is very large (up to $49.0 \mathrm{~m}$ ). Besides, this stratum is pure of salt, and the roof and bottom are all good enough to guarantee the sealing between layers.

From Table 3, we can see that this section contains seven mudstone interlayers with thickness of more than $1.0 \mathrm{~m}$ (the maximum is $2.5 \mathrm{~m}$ ). The sealing capacity of the nonsalt interlayers is lower than salt. Therefore, the interlayers are the weak positions for tightness of oil storage (discussed in Sections 4.2 and 4.3).

4.1.3. Bottom of Salt Bed (Immediate Bottom of Oil Storage). In this section, the depth is 1055.0 to $1110.0 \mathrm{~m}$ and the apparent thickness is $55.0 \mathrm{~m}$. The lithology is mainly interlayer of grey mudstone and dark brown mudstone, which is relatively hard and can be used as the excellent bottom of salt cavern storage. 
TABLE 3: Stratum distribution of Well M1\# Ef $f^{4}$.

\begin{tabular}{|c|c|c|c|c|c|}
\hline Number & Lithotype & $\begin{array}{c}\text { Top depth } \\
(\mathrm{m})\end{array}$ & $\begin{array}{c}\text { Bottom depth } \\
(\mathrm{m})\end{array}$ & $\begin{array}{c}\text { Thickness } \\
(\mathrm{m})\end{array}$ & Comment \\
\hline 1 & Rock salt & 860.0 & 891.0 & 31.0 & \\
\hline 2 & Mudstone & 891.0 & 893.0 & 2.0 & Interlayer \\
\hline 3 & Rock salt & 893.0 & 910.5 & 6.5 & \\
\hline 4 & Mudstone & 910.5 & 912.0 & 1.5 & Interlayer \\
\hline 5 & Rock salt & 912.0 & 955.0 & 33.0 & \\
\hline 6 & Mudstone & 955.0 & 956.0 & 1.0 & Interlayer \\
\hline 7 & Rock salt & 956.0 & 967.0 & 11.0 & \\
\hline 8 & Mudstone & 967.0 & 968.5 & 1.5 & Interlayer \\
\hline 9 & Rock salt & 968.5 & 970.0 & 1.5 & \\
\hline 10 & Mudstone & 970.0 & 971.5 & 1.5 & Interlayer \\
\hline 11 & Rock salt & 971.5 & 973.5 & 2.0 & \\
\hline 12 & Mudstone & 973.5 & 976.0 & 2.5 & Interlayer \\
\hline 13 & Rock salt & 976.0 & 1025.0 & 49.0 & \\
\hline 14 & Mudstone & 1025.0 & 1027.0 & 2.0 & Interlayer \\
\hline 15 & Rock salt & 1027.0 & 1055.0 & 28.0 & \\
\hline
\end{tabular}

TABLE 4: TSE results of interlayers in Well M1\#.

\begin{tabular}{lclrr}
\hline Number & $\begin{array}{c}\text { Depth } \\
(\mathrm{m})\end{array}$ & Lithotype & $\begin{array}{c}\text { Mud } \\
(\%)\end{array}$ & $\begin{array}{c}\text { Silt } \\
(\%)\end{array}$ \\
\hline TSE-38 & $891.0 \sim 893.0$ & Mudstone & 95.0 & 0.5 \\
TSE-41 & $910.5 \sim 912.0$ & Mudstone & 97.0 & 0.5 \\
TSE-47 & $955.0 \sim 956.0$ & Mudstone & 95.5 & 2.0 \\
TSE-49 & $967.0 \sim 968.5$ & Mudstone & 95.0 & 4.0 \\
TSE-52 & $973.5 \sim 976.0$ & Mudstone & 92.0 & 8.0 \\
TSE-53 & $973.5 \sim 976.0$ & Mudstone & 96.0 & 3.0 \\
& Average & & 95.1 & 3.0 \\
\hline
\end{tabular}

\subsection{Composition of Interlayers}

4.2.1. Thin Section Examination (TSE). The mineral composition and types of the interlayers were measured by TSE under polarized light microscope using representative cores of Well M1\#. The results are shown in Table 4 , from which we can see that the lithology of interlayers is all mudstone with $95.1 \%$ average mud content and little silt. As a result, the relative pure interlayers with good sealing ability are helpful to the tightness of oil storage.

4.2.2. X-Ray Diffraction (XRD). Based on the above analysis, the main composition of interlayers is mudstone, which is mainly composed of clay minerals. The main types of clay minerals were carried out by X-ray diffraction analysis. As shown in Table 5 , the contents of glimmerton, illite/smectite mixed layer, and chlorite are $75.0 \%, 16.4 \%$, and $8.2 \%$, respectively. On one hand, it is well known that glimmerton is not easy to expand when immersed into water, which can effectively reduce the damage caused by the interlayers during the water-soluble mining process. Hence, it is good for the mechanics and sealing of surrounding rock. On the other hand, a small quantity of illite/smectite mixed layer that is easy to expand when immersed into water is beneficial to fill the microcracks in layers and improve the sealing ability of oil storage.

According to the mineralogical analysis above, the main component of interlayers is mudstone (Table 4) and the main clay mineral content of mudstone is glimmerton (Table 5). All relative minerals would not react obviously with the main ingredients of crude oil (hydrocarbon), which is indicative of stability and good quality of crude oil stored in the strata.

\subsection{Tightness of Interlayers}

4.3.1. Scanning Electron Microscope (SEM). Some micropores were found in the interlayers by thin section examination. In order to further explore the microstructure characteristics of micropores, scanning electron microscope was measured. Figure 4 shows the typical SEM images of mudstone interlayer at different magnification. At low magnification (Figure 4(a)), we can see the micropores and heterogeneous distribution of halite. However, the distribution of micropores is slightly directional with increase of magnification (Figure 4(b)). At high magnification (Figure 4(c)), we can see that the rich development micropores are filled with a large number of 
TABLE 5: XRD analysis results of clay minerals in interlayers of Well M1\#.

\begin{tabular}{lccccc}
\hline Number & $\begin{array}{c}\text { Depth } \\
(\mathrm{m})\end{array}$ & $\begin{array}{c}\text { Glimmerton } \\
(\%)\end{array}$ & $\begin{array}{c}\text { Kaolinite } \\
(\%)\end{array}$ & $\begin{array}{c}\text { Chlorite } \\
(\%)\end{array}$ & $\begin{array}{c}\text { Illite/smectite mixed layer } \\
(\%)\end{array}$ \\
\hline XRD-37 & $891.0 \sim 893.0$ & 80 & 0 & 10 & 10 \\
XRD-38 & $891.0 \sim 893.0$ & 74 & 0 & 6 & 20 \\
XRD-39 & $891.0 \sim 893.0$ & 71 & 0 & 10 & 22 \\
XRD-47 & $955.0 \sim 956.0$ & 75 & 0 & 8 & 15 \\
XRD-49 & $967.0 \sim 968.5$ & 72 & 3 & 7 & 20 \\
XRD-51 & $970.0 \sim 971.5$ & 85 & 0 & 12 & 5 \\
XRD-52 & $973.5 \sim 976.0$ & 75 & 0 & 6 & 20 \\
XRD-53 & $973.5 \sim 976.0$ & 75.0 & 0.4 & 8.2 & 19 \\
& Average & & & \\
\end{tabular}

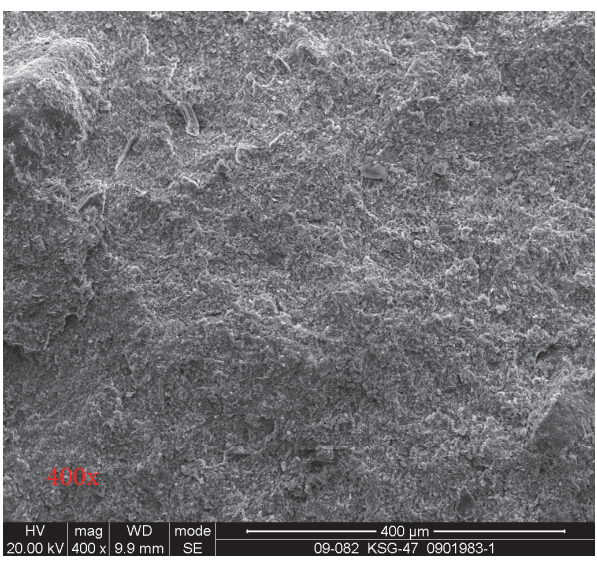

(a)

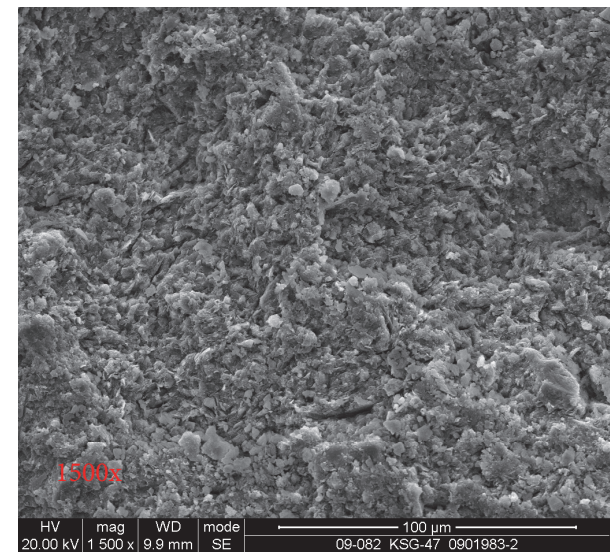

(b)

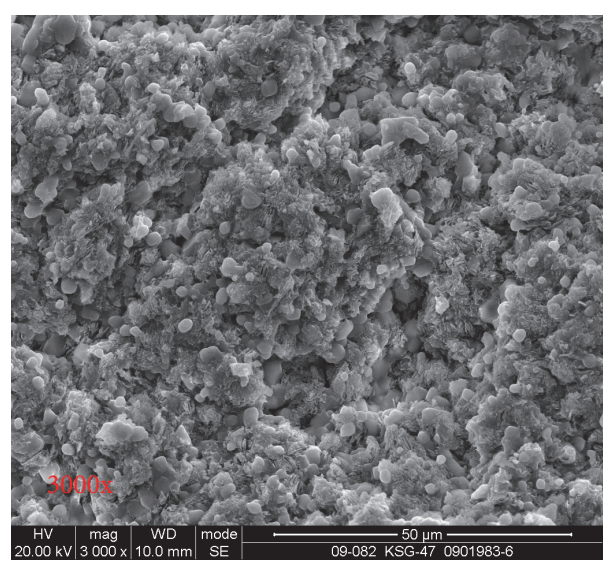

(c)

FIGURE 4: SEM images of a mudstone interlayer at different magnification.

oil droplet-like and membrane-like rock salt crystals, which can effectively prevent the leakage of oil molecules from oil storage.

4.3.2. Mercury Intrusion Porosimetry (MIP). Furthermore, the MIP measurements were conducted to evaluate the characteristics of interlayer samples, and the results are shown in Table 6. Deng et al. divided the cap rock of natural gas reservoirs cap rock into six grades by breakthrough pressure [29]. As seen in Table 6, the mean value of the breakthrough pressure is 7.69 MPa. Even as the cap rock of oil/gas reservoir, it is located within the second and third grades, which is an effective barrier. It is known that the geological history of the oil/gas reservoirs is much longer than the oil/gas storage. 
TABLE 6: MIP test results of interlayers in Well M1\#.

\begin{tabular}{|c|c|c|c|c|c|}
\hline Number & $\begin{array}{c}\text { Depth } \\
(\mathrm{m})\end{array}$ & $\begin{array}{l}\text { Breakthrough pressure } \\
\qquad(\mathrm{MPa})\end{array}$ & $\begin{array}{l}\text { Breakthrough radius } \\
(\mathrm{nm})\end{array}$ & $\begin{array}{c}\text { Median pressure } \\
(\mathrm{MPa})\end{array}$ & $\begin{array}{c}\text { Median radius } \\
(\mathrm{nm})\end{array}$ \\
\hline MIP-37 & $891.0 \sim 893.0$ & 6.87 & 20.380 & 22.22 & 6.301 \\
\hline MIP-38 & $891.0 \sim 893.0$ & 6.25 & 21.430 & 31.69 & 4.418 \\
\hline MIP-39 & $891.0 \sim 893.0$ & 3.91 & 35.840 & 23.13 & 6.052 \\
\hline MIP-47 & $955.0 \sim 956.0$ & 10.64 & 13.160 & 42.88 & 3.265 \\
\hline MIP-49 & $967.0 \sim 968.5$ & 12.86 & 10.890 & 51.06 & 2.742 \\
\hline MIP-51 & 970.0 971.5 & 4.17 & 33.540 & 15.72 & 8.907 \\
\hline MIP-52 & $973.5 \sim 976.0$ & 7.27 & 18.710 & 46.76 & 2.994 \\
\hline MIP-53 & $973.5 \sim 976.0$ & 9.55 & 14.670 & 47.76 & 2.931 \\
\hline \multicolumn{2}{|c|}{ Maximum } & 12.86 & 35.840 & 47.76 & 8.907 \\
\hline \multicolumn{2}{|c|}{ Minimum } & 3.91 & 10.890 & 15.72 & 2.742 \\
\hline \multicolumn{2}{|c|}{ Average } & 7.69 & 21.080 & 35.15 & 4.700 \\
\hline
\end{tabular}

TABLE 7: Data results of sonar surveys.

\begin{tabular}{lccccc}
\hline $\begin{array}{l}\text { Salt cavern } \\
\text { Number }\end{array}$ & $\begin{array}{c}\text { Nadir } \\
(\mathrm{m})\end{array}$ & $\begin{array}{c}\text { Peak } \\
(\mathrm{m})\end{array}$ & $\begin{array}{c}\text { Height } \\
(\mathrm{m})\end{array}$ & $\begin{array}{c}\text { Maximum radius } \\
(\mathrm{m})\end{array}$ & $\begin{array}{c}\text { Cavern volume } \\
\left(\times 10^{4} \mathrm{~m}^{3}\right)\end{array}$ \\
\hline X1 & 1013.4 & 959.5 & 53.9 & 52.6 & 15.6 \\
X2 & 1007.4 & 937.4 & 70.0 & 44.4 & 15.9 \\
D1 & 1016.9 & 955.1 & 61.8 & 45.6 & 18.7 \\
D2 & 1012.3 & 958.4 & 53.9 & 47.1 & 18.9 \\
G1 & 1020.1 & 966.4 & 53.7 & 41.9 & 14.0 \\
G2 & 1015.3 & 955.8 & 59.5 & 46.1 & 15.4 \\
\hline
\end{tabular}

So, the sealing evaluating criteria of storage are higher and stricter than reservoirs. Thus, the interlayers are all effective sealing rock layers for oil storages.

\section{Evaluation of Existing Salt Caverns}

5.1. Volume and Shape Characteristics. Figure 5 and Table 7 show the salt cavern shapes and data measured by sonar in Jintan salt mine [30]. The effective volume of a single salt cavern can be up to $19 \times 10^{4} \mathrm{~m}^{3}$, which is a very large storage volume, by single-well water solution mining. It is inferred that the salt formation is suitable to build large-scale underground oil storage.

However, as we can see from Figure 5, some shapes of salt cavities in Jintan salt mine are irregular, which are unfavorable to the mechanical stability of oil storage. Meanwhile, the roofs were unprotected during the watersoluble mining, so the salt roof and even cap rock might be eroded or penetrated by water, resulting in reduction of sealing ability. Therefore, to effectively control the cavern shape and protect the salt roof, the suggested construction technology of salt cavern oil storage is illustrated in Figure 6, referring to overseas experience of salt cavern construction. Importantly, diesel oil is selected as cushion to protect the cavern roof.

5.2. Salt Cavern Tightness Tests. All tightness tests mentioned above are in laboratory scale except for the geological evaluation. So, it is necessary to ascertain the macroscopic sealing

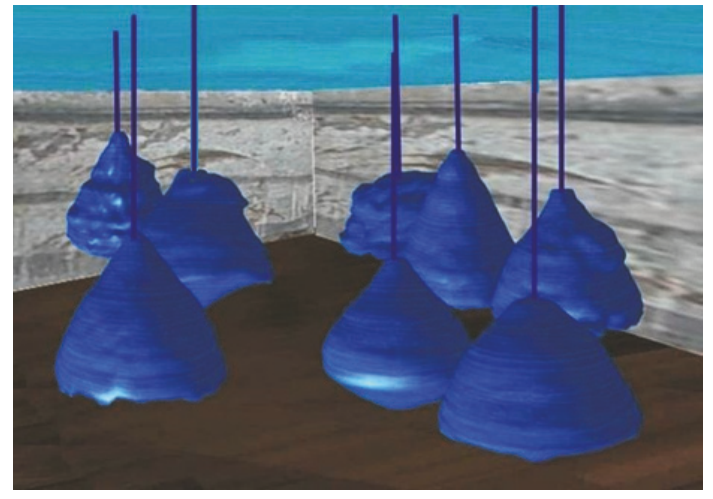

FIGURE 5: Sonar surveys of several existing salt caverns.

characteristics through field tests in Jintan salt mine. The tightness tests of existing salt caverns were analyzed based on the shut in sealing tests of salt caverns in Jintan salt mine [31]. The two salt caverns are located at in the south (Cavern Mao-1 in Figure 3) and north (Cavern Rong-1 in Figure 3) of the salt basin. So, their characteristics have good representativeness for the whole salt mine.

Based on the principle of liquid pressure balance in a salt cavern well, an equation is established:

$$
P_{\text {Cavern }}=P_{\text {Wellhead }}+\rho g h,
$$

where $P_{\text {Cavern }}$ is the pressure of brine or oil at depth $h$ in a salt cavern; $P_{\text {Wellhead }}$ is the wellhead pressure; $\rho$ is the density 


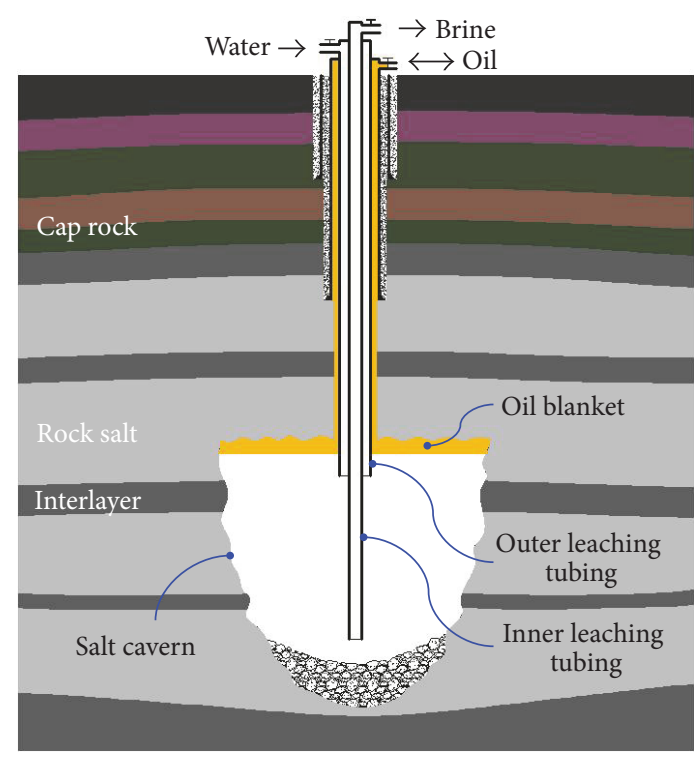

FIGURE 6: Suggested construction technology of salt cavern oil storage.

of brine or oil ( $\rho_{\text {brine }}$ is $1.20 \times 10^{3} \mathrm{~kg} / \mathrm{m}^{3}$ and $\rho_{\text {oil }}$ is $0.85 \times$ $\left.10^{3} \mathrm{~kg} / \mathrm{m}^{3}\right) ; g$ is the acceleration of gravity which is $9.8 \mathrm{~m} / \mathrm{s}^{2}$; $h$ is the depth.

5.2.1. Cavern Mao-1. The saliferous strata depth of this cavern is between $858.00 \mathrm{~m}$ and $1029.97 \mathrm{~m}$. The depth of cavern peak is located at $879.57 \mathrm{~m}$. The bottom of the cemented casings was located at $1008.38 \mathrm{~m}$ at the beginning of cavern leaching.

After this well was shut for 3 months, the wellhead pressure was stable at $3.95 \mathrm{MPa}\left(P_{\text {Wellhead }}\right.$ in $\left.(1)\right)$. It is indicated that the tightness of cemented casings is well under this wellhead pressure. The middle depth of this salt cavern is located at $975.5 \mathrm{~m}$ ( $h$ in (1)). The brine pressure at this depth is $15.42 \mathrm{MPa}\left(P_{\text {Cavern }}\right.$ in (1)). It is indicated that the tightness of cavern is under this cavern pressure.

If oil is stored in this cavern, the oil pressure in the middle depth of the cavern will be only $12.08 \mathrm{MPa}\left(P_{\text {Cavern }}\right.$ in (1)) under the same wellhead pressure $(3.95 \mathrm{MPa})$. It is obvious that $12.08 \mathrm{MPa}$ is lower than $15.42 \mathrm{MPa}$. Therefore, the above analysis indicated that the Cavern Mao-1 and its cemented casings can reach the tightness requirements for oil storage.

5.2.2. Cavern Rong-1. The saliferous strata depth of this cavern is between $932.00 \mathrm{~m}$ and $1064.21 \mathrm{~m}$. The depth of cavern peak is located at $979.30 \mathrm{~m}$. The bottom of the cemented casings was located at $1016.91 \mathrm{~m}$ at the beginning of cavern leaching.

Similarly, the wellhead pressure was stable at $4.30 \mathrm{MPa}$ $\left(P_{\text {Wellhead }}\right.$ in (1) $)$ after this well was shut for 3 months. It is indicated that the tightness of cemented casings is well under this wellhead pressure. The middle depth of this salt cavern is located at $998.0 \mathrm{~m}$ ( $h$ in (1)). The brine pressure at this depth is $16.04 \mathrm{MPa}\left(P_{\text {Cavern }}\right.$ in $\left.(1)\right)$. It is indicated that the tightness of cavern is under this cavern pressure.
If oil is stored in this cavern, the oil pressure in the middle depth of the cavern will be only $12.61 \mathrm{MPa}\left(P_{\text {Cavern }}\right.$ in (1)) under the same wellhead pressure $(4.30 \mathrm{MPa})$. It is obvious that $12.61 \mathrm{MPa}$ is lower than $16.04 \mathrm{MPa}$. Therefore, the above analysis indicated that the Cavern Mao-1 and its cemented casings can reach the tightness requirements for oil storage.

It can be inferred that there is no serious leakage in the two salt caverns because the wellhead pressure can reach stable values $(3.95 \mathrm{MPa}$ and $4.30 \mathrm{MPa})$. However, the wellhead pressure may be influenced by creep closure of a salt cavern, thermal expansion of brine, and permeation loss of brine. So, the tightness tests for the two existing caverns are preliminary. In the further in-depth research, several more detailed tightness tests will be carried out. For example, fill the annular space with nitrogen or diesel oil to develop an interface below the last cemented casing and measure interface depth changes during a couple of days.

\section{Conclusions}

In conclusion, the following favorable geological conditions are good for the construction of underground oil storage in Jintan salt mine of China.

\subsection{Simple Geological Structure and Clear Strata Sedimentary} Characteristics. The distribution of salt layers is relatively stable in plane and vertical direction in Jintan mining area, and the large faults are located in the mining boundary with clear distribution. Besides, the regional earthquake seldom happens and the waterproof condition of strata is good enough to guarantee the security of oil storage.

6.2. Wide Distribution and Large Thickness. The saliferous strata are located in the 4 th part of Funing group $\left(\mathrm{Ef}^{4}\right)$ with large area of $60.5 \mathrm{~km}^{2}$, great thickness of $67.85-230.95 \mathrm{~m}$, and sedimentary center thickness of at least $200 \mathrm{~m}$. Additionally, the depth of $\mathrm{Ef}^{4}$ is $809.38 \sim 1045.57 \mathrm{~m}$, which is also very suitable for the security and stable operation of underground oil storage.

6.3. Excellent Strata Sealing Condition. The immediate roof and cap rock of salt strata are mainly composed of mudstone with excellent sealing ability. The results by microscopic tests revealed that the high breakthrough pressure $(1.36 \sim 5.71 \mathrm{MPa})$ and low permeability $\left(2.93 \sim 6.90 \times 10^{-11} \mathrm{~m}^{2}\right)$ were beneficial to the tightness of cap rock. From the analysis of rock cores, the composition of nonhalite interlayers was mainly mudstone, which was dense and hard evidenced by SEM images.

6.4. Large Volume and Good Tightness of the Salt Caverns. The results measured by sonar showed that the effective volume of a single salt cavern is up to $19 \times 10^{4} \mathrm{~m}^{3}$ by single-well water solution mining. Moreover, the volume of single salt cavern could be larger if the suggested construction technology of salt cavern oil storage would be applied. Finally, the tightness tests on existing salt caverns (Cavern Mao-1 and Cavern 
Rong-1) illustrated that the two caverns and their cemented casings can reach the tightness requirements for oil storage.

To sum up, Jintan salt mine has the basic geological conditions for constructing the large-scale underground oil storage, which could become the first salt cavern oil storage group base in China.

\section{Conflicts of Interest}

The authors declare that they have no conflicts of interest.

\section{Acknowledgments}

The research was supported by the National Natural Science Foundation of China (nos. 51404241, 51574048, 41672292, 51604044, and 41472285), the Doctoral Program of Higher Specialized Research Fund Project (no. 20130191130003), the Fundamental Research Funds for the Central Universities (nos. 106112016CDJZR245518 and 106112016CDJCR241219), the China Postdoctoral Science Foundation (no. 2015M582520 and no. 2015T80857), and the Chongqing Postdoctoral Special Foundation (no. Xm2016028). The authors would gratefully like to acknowledge the cooperation and support from the Sinopec and Jintan salt mine related personnel and the testing staff's hard work.

\section{References}

[1] C. Tian, "Oil import and export in China," China Oil \& Gas, pp. 36-42, 2016.

[2] P. Cosenza, M. Ghoreychi, B. Bazargan-Sabet, and G. D. Marsily, "In situ rock salt permeability measurement for long term safety assessment of storage," International Journal of Rock Mechanics \& Mining Sciences, vol. 36, no. 4, pp. 509-526, 1999.

[3] W. Liu, Y. P. Li, C. H. Yang, J. J. K. Daemen, Y. Yang, and G. Zhang, "Permeability characteristics of mudstone cap rock and interlayers in bedded salt formations and tightness assessment for underground gas storage caverns," Engineering Geology, vol. 193, pp. 212-223, 2015.

[4] K. S. Chan, D. E. Munson, S. R. Bodner, and A. F. Fossum, "Cleavage and creep fracture of rock salt," Acta Materialia, vol. 44, no. 9, pp. 3553-3565, 1996.

[5] H. W. Zhou, C. P. Wang, L. Mishnaevsky Jr., Z. Q. Duan, and J. Y. Ding, "A fractional derivative approach to full creep regions in salt rock," Mechanics of Time-Dependent Materials, vol. 17, no. 3, pp. 413-425, 2013.

[6] M. Langer, "Use of solution-mined caverns in salt for oil and gas storage and toxic waste disposal in Germany," Engineering Geology, vol. 35, no. 3-4, pp. 183-190, 1993.

[7] P. Bérest and B. Brouard, "Safety of salt caverns used for underground storage blow out; mechanical instability; seepage; cavern abandonment," Oil \& Gas Science and Technology, vol. 58, no. 3, pp. 361-384, 2003.

[8] A. Ozarslan, "Large-scale hydrogen energy storage in salt caverns," International Journal of Hydrogen Energy, vol. 37, no. 19, pp. 14265-14277, 2012.

[9] Q. Y. Zhang, K. Duan, Y. Y. Jiao, and W. Xiang, "Physical model test and numerical simulation for the stability analysis of deep gas storage cavern group located in bedded rock salt formation,"
International Journal of Rock Mechanics \& Mining Sciences, vol. 94, pp. 43-54, 2017.

[10] Y. P. Li, C. H. Yang, and X. L. Shi, "Leaching control and safety assessment of salt cavern gas storage: science press," 2012.

[11] G. Zhang, Y. Li, C. Yang, and J. J. K. Daemen, "Stability and tightness evaluation of bedded rock salt formations for underground gas/oil storage," Acta Geotechnica, vol. 9, no. 1, pp. 161-179, 2014.

[12] G. Wang, W. Xing, J. Liu, Z. Hou, and P. Were, "Influence of water-insoluble content on the short-term strength of bedded rock salt from three locations in China," Environmental Earth Sciences, vol. 73, no. 11, pp. 6951-6963, 2015.

[13] J. Chen, L. Li, L. M. Yin, S. Ren, and L. Yi, “The flow field characteristics in salt caverns with similar experiment," Energy Education Science and Technology Part A: Energy Science and Research, vol. 31, no. 3, pp. 1437-1442, 2013.

[14] C. H. Yang, Y. P. Li, F. Chen, X. L. Shi, and D. N. Qu, "Advances in researches of the mechanical behaviors of deep bedded salt rocks in China," Advances in Mechanics, 2009.

[15] L. J. Ma, X. Y. Liu, M. Y. Wang et al., "Experimental investigation of the mechanical properties of rock salt under triaxial cyclic loading," International Journal of Rock Mechanics \& Mining Sciences, vol. 62, no. 9, pp. 34-41, 2013.

[16] L. J. Ma, H. F. Xu, Q. Tong, L. Dong, N. Zhang, and J. Li, "Post-yield plastic frictional parameters of a rock salt using the concept of mobilized strength," Engineering Geology, vol. 177, pp. 25-31, 2014.

[17] G. Zhang, Y. Wu, L. Wang, K. Zhang, J. J. K. Daemen, and W. Liu, "Time-dependent subsidence prediction model and influence factor analysis for underground gas storages in bedded salt formations," Engineering Geology, vol. 187, pp. 156169, 2015.

[18] G. Wang, L. Zhang, Y. Zhang, and G. Ding, "Experimental investigations of the creep-damage-rupture behaviour of rock salt," International Journal of Rock Mechanics and Mining Sciences, vol. 66, no. 1, pp. 181-187, 2014.

[19] H. P. Xie, J. F. Liu, Y. Ju, J. Li, and L. Z. Xie, "Fractal property of spatial distribution of acoustic emissions during the failure process of bedded rock salt," International Journal of Rock Mechanics and Mining Sciences, vol. 48, no. 8, pp. 1344-1351, 2011.

[20] A. M. Wang, C. H. Yang, J. W. Chen, X. Z. Zhang, and Z. Q. Huang, "Composite materials method for studying mechanical and deformation properties of layered salt rock," in Proceedings of the 3rd International Conference on Heterogeneous Material Mechanics (ICHMM '11), Shanghai, China, May 2011.

[21] W. Liu, J. Chen, D. Y. Jiang et al., "Tightness and suitability evaluation of abandoned salt caverns served as hydrocarbon energies storage under adverse geological conditions (AGC)," Applied Energy, vol. 178, pp. 703-720, 2016.

[22] J. Xiong, X. L. Huang, and H. L. Ma, "Gas leakage mechanism in bedded salt rock storage cavern considering damaged interface," Petroleum, vol. 1, no. 4, pp. 366-372, 2015.

[23] N. Zhang, L. J. Ma, M. Y. Wang, Q. Y. Zhang, J. Li, and P. X. Fan, "Comprehensive risk evaluation of underground energy storage caverns in bedded rock salt," Journal of Loss Prevention in the Process Industries, vol. 45, pp. 264-276, 2017.

[24] Q. Q. Wanyan, L. Ran, B. J. Han, M. J. Cai, and Q. Li, "Study on site selection and evaluation of underground gas storage in salt cavern," Journal of Southwest Petroleum University, vol. 37, no. 1, pp. 57-64, 2015. 
[25] C. H. Yang, J. Chen, and X. L. Shi, Engineering Mechanics Experiment Research of Jintan Salt Cavern Gas Storage by Sinopec, Institute of Rock and Soil Mechanics, Chinese Academy of Sciences, 2009.

[26] C. E. Administration, The Ground Motion Parameter Zoning Map of China (the People's Republic of China National Standard GB 18306-2001), China Standards Press, 2001.

[27] L. Chen, J. Ye, and F. Zeng, Sample Tests And Analysis Research Report of Well M1\# Rock Cores, Sinopec Jingzhou exploration technology center, Jingzhou, China, 2009.

[28] Bureau SJPE, Logging reports of Well M1\#, 2009.

[29] Z. Y. Deng, S. C. Wang, Z. L. Jiang, and Z. N. Chen, "Breaking pressure of gas cap rocks," Oil and Gas Geology, vol. 21, no. 2, pp. 136-138, 2000.

[30] C. H. Yang, Availability Assessment of Existing Salt Caverns in Jintan Salt Mine, Institute of Rock and Soil Mechanics, Chinese Academy of Sciences, 2005.

[31] J. Y. Fang and Z. J. Xu, "Condition of constructing gas geostock in salt cavern in Jintan salt mine," China Well \& Rock Salt, vol. 38, no. 1, pp. 35-36, 2007. 

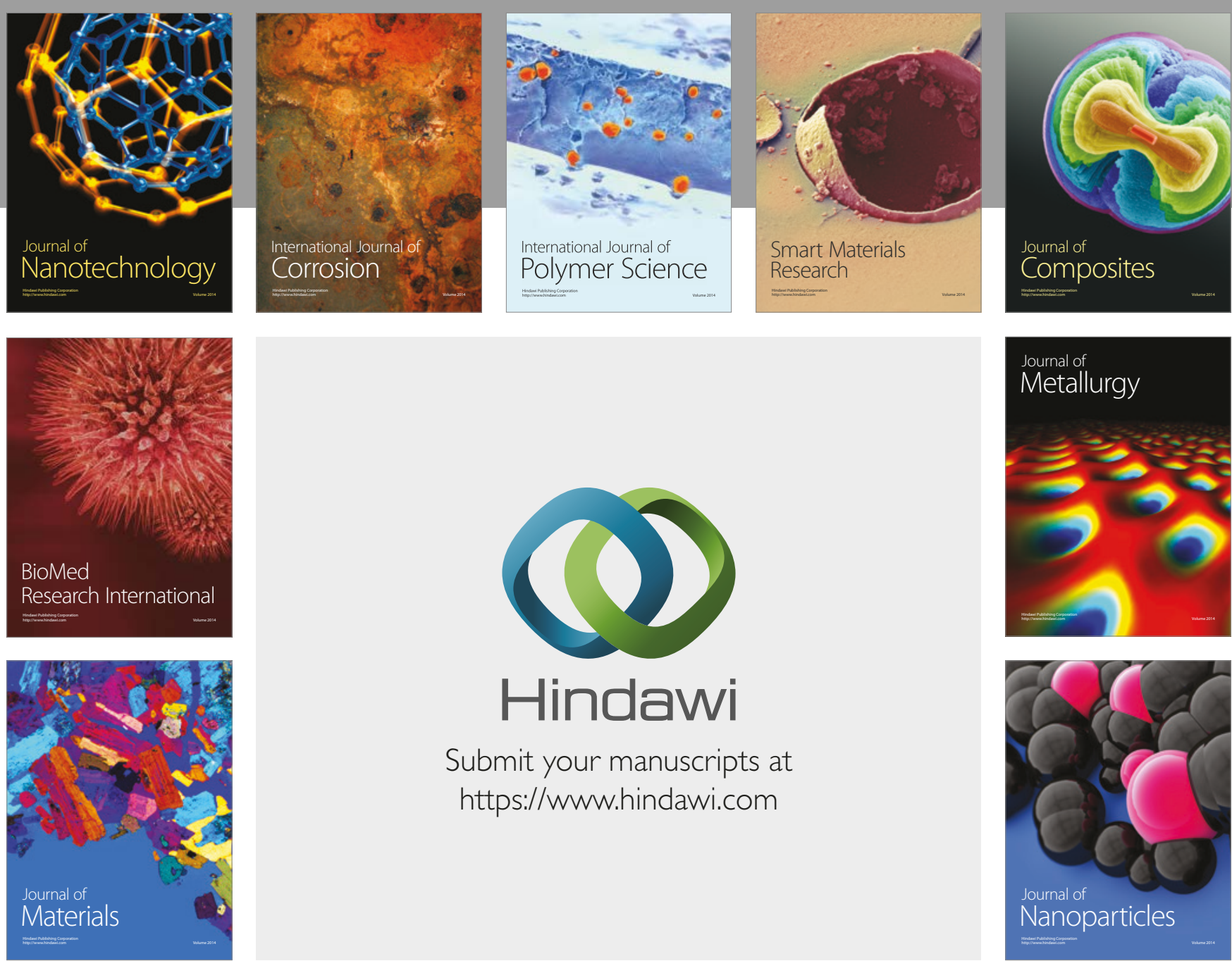

\section{Hindawi}

Submit your manuscripts at

https://www.hindawi.com
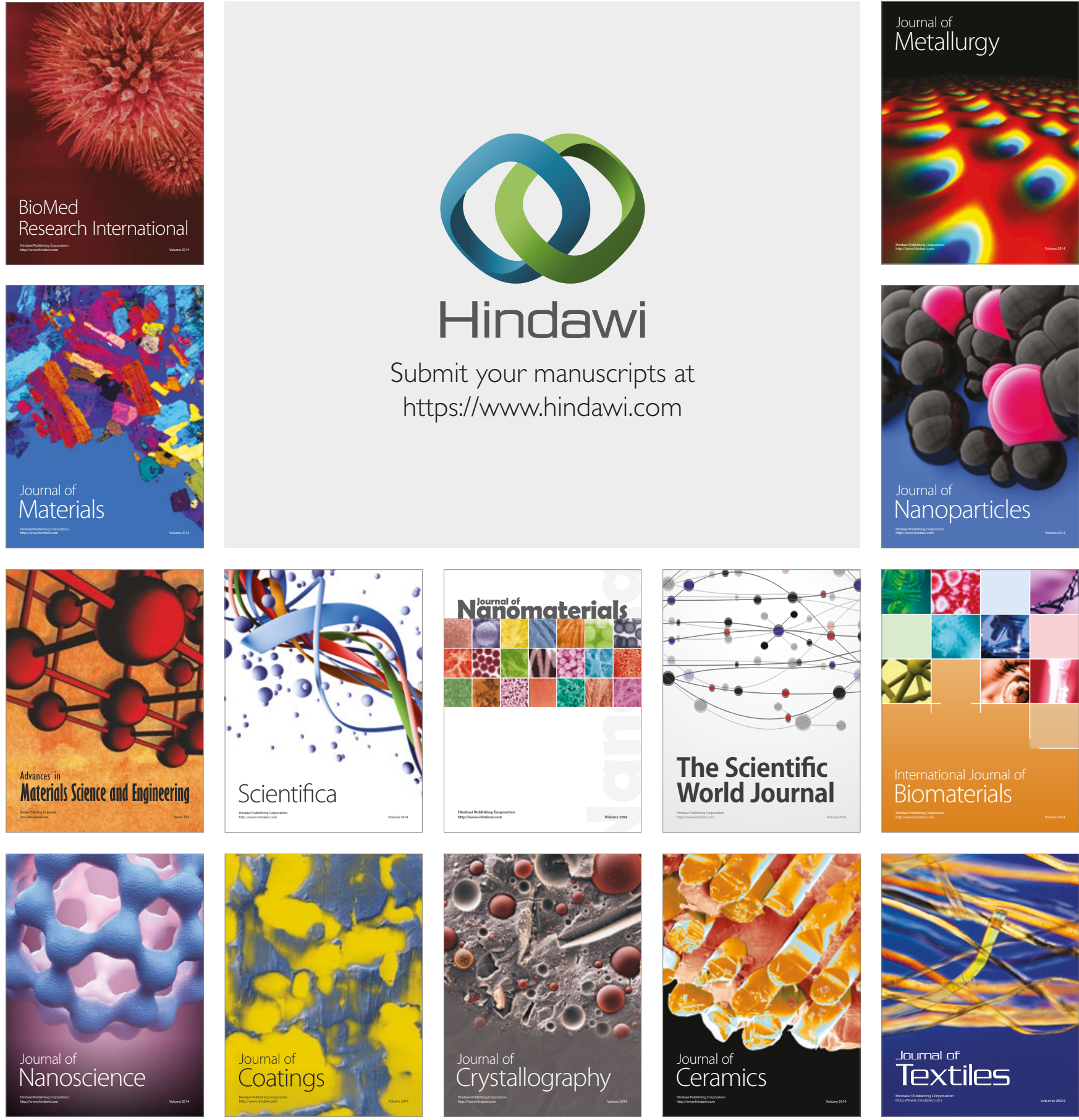

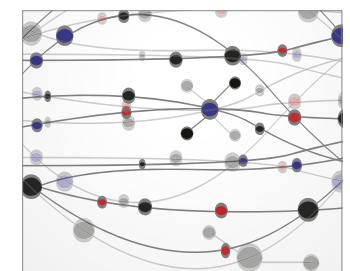

The Scientific World Journal
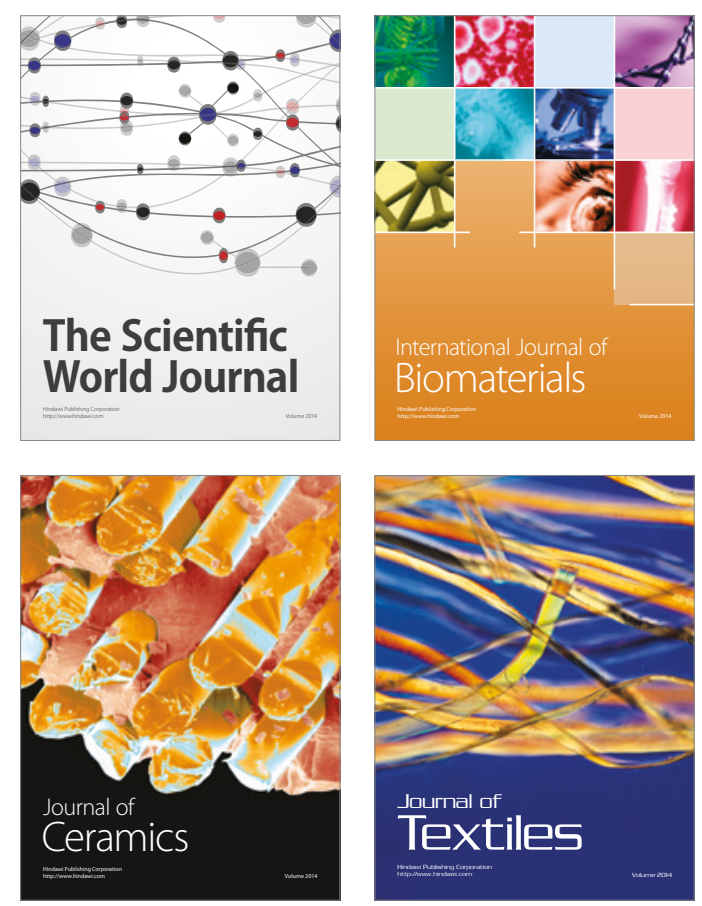